\title{
WELCOME AND OPENING REMARKS
}

Hello everyone and thank you for joining us today.

My name is Kate Seear. I am an Associate Professor in the Faculty of Law at Monash, and the Academic

Director of Springvale Monash Legal Service.

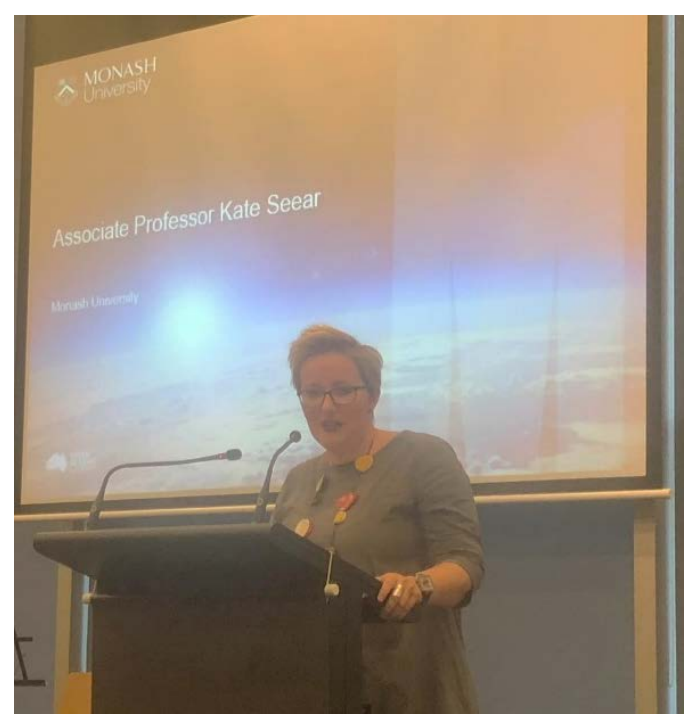

I would like to begin, as is customary, by acknowledging the traditional owners of the land on which we meet today - the Wurundjeri people of the Kulin nations - and to acknowledge elders past, present and emerging. I also take this opportunity to acknowledge that when these lands were invaded, Aboriginal and Torres Strait Islanders never ceded sovereignty and that they remain strong in their enduring connection to land and culture.

I'd like to welcome you all here today to this very special event - a Festschrift - in honour of the retirement our colleague, Professor Adrian Evans. Welcome to Adrian, to his partner Maria, and his family, to colleagues and friends.

Let's begin by addressing the elephant in the room. I know many of you want to know this, because you've all been emailing me.

What actually is a Festshcrift?

Given how many of you were unsure about it, I'm surprised to see you all here. 
Adrian himself feared that it was a 'roast'. We told him it wasn't, of course, in a bid to convince him to come along. Rest assured, there will be some jokes about Adrian's propensity for hugging and calling us all 'brother' later in the day, and the uncanny resemblance between Adrian and Ned Flanders.

The word Festschrift comes from the German. Like all good academics, I turned to Wikipedia for a definition. It's traditionally defined as:

a book of letters or a panel honoring a respected person, especially an academic, and presented during their lifetime. It generally takes the form of an edited volume, containing contributions from the honoree's colleagues, former pupils, and friends.

Today, our Festschrift for Adrian takes the form of a panel, where we will hear from colleagues and family members about the contributions Adrian has made, over many years, to clinical legal education and legal ethics, social justice and promoting access to justice, for vulnerable and marginalised members of our community. We have a star-studded line up.

The format is as follows: in the first half of the event we will hear from Professors MaryAnne Noone, Nigel Duncan, Peter Joy and Jeff Giddings, and from Carolyn Worth AM, about Adrian's life work. At about 2:45, we will break for afternoon tea, giving you all an opportunity to mingle and pass on your best wishes to Adrian, if you have not done so already.

We will then return for the final hour, where the mood will lift a little. We have a couple of surprises to come, including some more light-hearted reflections on 
Adrian's life and work, before we will hear from Adrian himself. The Dean of the Law Faculty, Professor Bryan Horrigan, will close proceedings at 4pm.

Now I should say before going any further that Adrian threw a spanner into the works just before we commenced, telling me that he didn't like 'the " $R$ " word' - retirement - because it sounds too final. And so I've done some quick research to find some synonyms we might use as an alternative. They include: resignation, fallback, abandonment, withdrawal, surrender, desertion, goodbye, departure, retreat and demise. Somehow I am not sure any of these will suit, either!

And so I was thinking about the recent announcement by actress Gwyneth Paltrow and musician Chris Martin that their marriage was coming to an end. Rather than announcing their 'divorce', they announced that they were going through a period of 'conscious uncoupling'. As I understand it, 'conscious uncoupling' signals a mutually respectful decision to go your separate ways, while not losing contact altogether. And I think this is the spirit in which we meet today: to celebrate Adrian's 'conscious uncoupling' from Monash and from academia, with the recognition that we will still be able to retain a connection to him, and him to us.

We are going to hear a lot about Adrian's career over the next three hours, but let's start with a brief refresher. Adrian completed a double degree in Law and Commerce at The University of Melbourne in 1972 and was admitted to the Supreme Court of Victoria on the $1^{\text {st }}$ of March 1974. In 1976, he completed a 
diploma in theology which was awarded by the Australian College of Theology, the forerunner to the University of Divinity. He completed his Masters thesis at Monash University in 1997 and his PhD in 2008.

Adrian has held numerous roles across the years, including: working at Price Waterhouse Coopers in 1975, as a legal advisor to students at the Monash Union in 1976, as a Solicitor in the LaTrobe Students Representative Council from 1976 to 1987, and as Coordinator of Clinical Legal Education in the Department of Legal Studies at LaTrobe University from 1977 to 1985 . He was the coordinator of the Springvale Legal Service (as it was then known) from 1988 - 2000, holding the roles of Lecturer, Senior Lecturer, Associate Professor and eventually full Professor at Monash University from 1988 until today. Adrian has won teaching awards and numerous grants, published 15 books (edited and authored) and numerous reports and articles on clinical legal education, legal ethics, virtue ethics and therapeutic jurisprudence, gender and ethics, lawyering and faith. Of course, you can't get a true sense of who a person is by reciting their CV, even though Adrian's CV is incredible. So I'd like to say a few words about who I think Adrian is.

I came to know Adrian in the late 1990s, when he taught me Lawyers' Ethics at Monash. Adrian had the dubious honour of leading a subject that pretty much every law student regarded as unbearably dull, given its focus on truly scintillating topics such as the trust account rules and lawyers' duties (to which I can only say: the students had a point). 
Alongside this, Adrian talked to us about lofty notions like justice, fairness, values and the common good. Adrian was, as I recall it, the first and only lecturer I'd ever had who talked to us about what kind of lawyer we wanted to be, how we could live an ethical life as a lawyer, what kind of impact we wanted to make in the world, and the importance of access to justice for society's underprivileged.

Adrian's profound musings about Aristotelian ethics, virtue ethics and the ageold question of what it means to truly "do good' were met with other age-old questions from his students such as: is this rubbish going to be on the exam and what answer will give me the most marks for the least effort?

But I was inspired - both because Adrian spoke of things that really mattered, and which had somehow disappeared from the curriculum of most other subjects, and because I was a bit of a dork. But Adrian embraced that and encouraged me. He was one of those lecturers who would stop and talk to you across the campus, ask how you were, and take an interest in what you cared about. He gave you life advice and career guidance - sometimes unsolicited, but always well meaning. After I worked for a few years in private practice and community legal centres I was unsure what I wanted to do. Adrian gave me my first ever opportunity in academia, hiring me to do research assistant work on an ethics project that was a response to British American Tobacco v Rola McCabe - the case that raised questions about the links between lawyers and 
big tobacco. Adrian had a strong sense of right and wrong and those values were ones I had not always seen in practice.

In this work, he made me and many others like me feel like there was a space for us in legal practice or academia, especially when we didn't want to take the well-trodden path of doing a corporate clerkship, articles at a big city firm, and racking up billable hours.

I could not have known then that Adrian would eventually become my boss at Monash. Like many others, I have benefitted enormously from Adrian's care, guidance and sensitivity. Adrian listens to, and cares about, people. He thinks carefully about the impact his words will have on you before he speaks. He is deeply empathetic. He has helped me deal with a myriad of challenges, including complex ethical dilemmas, student issues, workplace politics, and more. Adrian has also been an unbelievable support through personal challenges over the last couple of years, and I am extremely grateful to him for that. I know that I am not alone, either. It's actually the main reason why we have all come together to acknowledge him today.

In preparing for today's event, I asked a number of colleagues - present and past - to say something about what Adrian had meant to them over the years. When I reflected on them all, it turned out that they formed a neat little poem. So here is a poem in honour of Adrian. It is called Adrian is.

\section{Adrian is...}


Adrian is... The most amazing and awesome person. He is a man of integrity, encouraging and supportive with charm and wit; with a laugh that you can hear from afar and you know that all is good because Adrian is around! I count it as a privilege to have worked with Adrian over many years and know he is a friend.

Adrian is... The most cited clinician in a PhD thesis.

Adrian is... The only colleague who has suggested a mid day siesta could be beneficial! "Just lie down on the floor".

Adrian is... Someone who - when a small thunderstorm rolled in from WA was most welcoming, and provided generous encouragement \& support.

Adrian is... An insightful man.

Adrian is... Fond of outdoor wear and puffy vests. Any time. Any where.

Adrian is... Someone who exemplifies the four approaches to legal practice: a zealous advocate for high ethical standards; a trustee of the legal system; an agent for change to improve justice outcomes, and a lawyer who cares deeply about relationships with family, friends, colleagues and clients.

Adrian is... Someone who makes me feel like he's always got time for me and that he has no other pressing business. 
Special Issue: Adrian Evans Festschrift

And Adrian has been my supervisor, mentor, colleague, ethical compass and friend over many, many years - even though he deserves his retirement, I am going to feel quite lost without him.

I want to thank you all again for coming today. 